\title{
REKOLEKCJE BISKUPA JANA PAWEA WORONICZA DLA KLERYKÓW KRAKOWSKICH W 1820 ROKU
}

"JW Pasterz pierwszy zapewne $\mathrm{w}$ tej mierze z biskupów polskich dał uslyszeć glos swój w oratorium seminarium naszego" - pisal przejęty niezwykłością wydarzenia kleryk ${ }^{1}$. Wygłaszanie przez biskupa nauk rekolekcyjnych dla alumnów rzeczywiście stanowilo praktykę wyjątkową. Ale też i zaangażowanie rządzącego diecezja krakowską od $1815 \mathrm{r}$. biskupa w sprawy edukacji i formacji seminarzystów bylo niezwykłc. Już jako dziekan kapituly warszawskiej, Woronicz uczestniczyl w 1809 r. w pracach komisji powolanej przez Fryderyka Augusta $w$ celu przygotowania planu reorganizacji kształcenia, dyscypliny i uposażenia duchowieństwa oraz redagowal stosowny projekt ${ }^{2}$. Domagano się tam selekcji kandydatów do seminariów i obsadzania tych zakladów przez przygotowaną kadrę, a także ujednolicenia systemu studiów.

Realizacja dawnych przemyśleń i nowych oczekiwań, zglaszanych z Warszawy przez Komisję Wyznań Religijnych i Oświecenia Publicznego, okazywala się trudna nie tylko $w$ sferze nauczania ${ }^{3}$. Diecezja w granicach

1 Bibl. Ossolin. we Wrodawiu, Rkps 949: Czute uwagi tobrego pasterza do suych owieczek minne i) časie rekolekcji w miesincu marcu 1820 roku przez JW Jata Pawta Woronicza, biskupa diecezji krakowuskiej w semintirium diecezjalnym, $\mathrm{k} .1 \mathrm{v}$.

2 Projekt polepszenia stamu duchoionego prze deputacje podany. W: J.P. Woronicz, Pisma, Bibl. Jagiel., rkps 2808, t. 4, k. 113-234: A. Jougan, Ks. prymas Woronicz. Monografia, cz. 1. Lwów 1908, s. $115-116$.

3 J. Kracik, Sprawn reformy studiów w krakowskim seminarium duchownym za rz̨dóto biskupa Woronicza (1815-1828). „Roczniki Teologiczno-Kanoniczne”. T. 20:1973, z. 4, s. 35-54; tenże, Ahumi semintarium krakowoskiego wo okresie Wolnego Minsta (1815-1846). „Analecta Cracoviensia. T. 8:1976, s. 345-363: tenże, Spór o podręczniki teologii wo Wolnym Mieście Krakowie, "Nasza Przeszlośćc". T. 63: 1985 , s. $229-250$. 
określonych bulla Piusa VI Ex imposita nobis z 1818 r., obejmująca Rzeczpospolitą Krakowską (46 parafii) i Kielecczvznę w Królestwie Polskim (239 parafii), odczuwala brak księży. Biskup deklarowal swą troskliwość o to, „aby dla obu panstw diecezje jego składających, światlych i przykładnych dostarczal kaplanów"4.

Wysoko ceniąc akademickie studia skłonil profesorów krakowskiego Wydzialu Teologicznego, aby objęli czẹść wykladów w seminarium diecezjalnym, prowadzonym przez Zgromadzenie Misjonarzy. Ich przygotowanie Woronicz oceniał nisko, a nauczanie uznawal za schematyczne i szkolne, slabo przygotowujace przyszlych duszpasterzy do stawienia czola zarzutom ludzi oświeconych. Wskutek oporu ze strony misjonarzy biskup postanowil w 1818 r., by alumni uczęszczali na Wydzial i sluchali tam wykładów z pastoralnej i homiletyki. Gdy wobec tego misjonarze zagrozili rezygnacja, ordynariusz ustapil. W następnym roku skierowal do Akademii tylko najzdolniejszych kleryków. Podzielilo to seminarzystów i wywołało niejednolite traktowanie ich przez przełożonych ${ }^{5}$.

Sama młodzież duchowna, dorastając w epoce częstych zmian politycznych i wojen, też nie ułatwiała wychowrania. Niektórzy z alumnów mieli za soba wojskowa przeszłość. Misjonarze postanowili ują́ w karby bujne temperamenty. Jeden z nich pisal w 1817 r.: "Wzięliśmy ściśle kleryków, a lekcje i wszystko w seminarium jak zegar regularnie iść zaczęło. Zaczęli narzekać i skarżyć się klerycy na ścisle trzymanie siebie i regularność, do której nie byli przyzwyczajeni, a to dało okazje do pilnego nas uważania"b. Część krakowskiego duchowieństwa uznawała słuszność stosowanych rygorów. Inni oceniali je jako brutalne. Alumni usuwani $z$ seminarium, także za pijaństwo, udawali się do biskupa ze skargą na przełożonych i przedstawiali się jako ofiary szykan, dodając inne, bardziej czy mniej słuszne zarzuty przeciw misjonarzom. Komisja wyznaczona przez Woronicza do zbadania sprawy pod koniec 1819 r., działając niezręcznie zaogniła jeszcze antagonizm? ${ }^{7}$. Delegat biskupa doprowadził $w$ końcu do przeproszenia przełożonych przez kleryków. Nie znikly jednak pokłady wzajemnej nieufności. Misjonarze poprosili swego wizytatora w Warszawie o zabranie ich z Krakowa.

Woronicz postawiony wobec perspektywy ewakuacji seminarium z przełożonych $w$ środku roku szkolnego, przybyl na Stradom 29 Il 1820 r. i rzekł do misjonarzy: "Pierwszy i jedyny czyn będzic w historii śviatata, żebyy

\footnotetext{
4 Archiwum UJ, S I 306: Woronicz do Senatu W.M. Krakowa, 29 IX 1819.

5 J. Kracik, Sprawa reforny, s. 41-43; tenże, Alumni seminarium, s. 361.

6 W. Malinowski, Opisanie krótkie dziejów domu księży misjonazótw $i$ seminarizun diecezjalnego to Krakowie na Strutomiu of roku 1817. (Rękopis w posiadaniu Archiwum Księży Misjonarzy w Krakowie, pod sygn. P II 9a), s. 6.

7 Archiwum Kurii Metropolitalnej w Krakowie, Akta konsystorza 1819. Protokól przesluchania alumnów, 26-29, 31 XII 1819, nr 1959; W. Malinowski, Opisanie, s. 8, 24, 27-30, 86.
} 
biskup swoich podleglych przepraszal i usprawiedliwial sie przed nimi”. Po czym „zacząl prosić po przyjacielsku, żebyśmy go ratowali, bo go już ısszyscy odstẹpuja, a gdy i my go odstąpimy, wszystko zginać musi. Prosil najbardziej o sposób, jakim by można to zagladzić, co się w seminarium stało, a karność w klerykach przywrócić" $"$. Milczenie indagowanych przerwal jeden $z$ nich, ks. Gorzkiewicz, mówiąc iż potrzeba mocnego regulaminu, rekolekcji j dobrych spowiedników. Biskup skwapliwie podjął watek, polecając wybrać najlepszych sporviedników od dominikanów i reformatów, czekające na jego zatwierdzenie reguly życia seminaryjnego obiecal obostrzyć „na tych brutalów góralów”, a nadto „sam przyrzekl na rekolekcje przyjechać i rąbać kleryków na konferencjach"9.

Rekolekcje rozpoczęły się 19 marca. Notatki jednego ze sluchaczy pozwalaja nie tylko poznać tematykẹ poruszaną na konferencjach, ale stwarzają też rzadka okazje obserwacji pojmowania wzajemnych ról i odniesień, wyrażanych słowem czy gestem biskupa oraz alumnów. Woronicz zamieszkal w seminarium. Glosil co wieczór jednogodzinne nauki. $W$ sumie bylo ich cztery. Pozostałe wyglaszał ks. Gorzkiewicz. Biskup wraz z słuchaczami codziennie uczestniczyl we Mszy św. "na zgotowanym dla niego umyślnie na to tronie z boku oltarza. Klęczał ustawicznie, zalewając sie gorzkimi lzami i wzdychając do Pana zastępów. Za nasze dobro Ojca Niebieskiego blagal! Spoglądal na nas często, prawdziwie miłością ojcowską ku nam palając" ${ }^{10}$. Każdą konferencje rozpoczynal od Veni sancte Spiritus, a kończył pasterskim blogosławieństwem. Po zakoniczonych rekolekcjach, zanim wsiadl w oczekujący powóz, klerycy odprowadzili go do furty, "gdzie jeszcze nie jeden ucalowal drogie stopy jego". Dwa dni wcześniej "tak nawet uniżył się, iż z niezmiernym ukontentowaniem naszym przybyl do refektarza, gdzie obiad jadl z nami".

W pierwszej konferencji, po wstępnej zachęcie i ukazaniu przykladów ludzi, którzy odprawiali rekolekcje (Ludwik XVIII, Stanisław August, król saski Fryderyk), Woronicz przeszedl do omawiania motywów wstąpienia do stanu duchownego. Dawniej - tlumaczyl alumnom - księża byli szanowani i bogaci. Niskie nieraz pobudki pchały ludzi do kapłaństwa. Dziś warunki się zmienily, duchownych spotyka pogarda, są ubodzy. Szczęście, że słuchacze urodzili się $w$ takich czasach. Materialne względy nie będą im torować drogi do oltarza! Jeśli przywiodła ich tu troska o chwalę Boża, to należy się cieszyć. Ale biada, gdyby jednak nadzieja zysku, interes. Lepiej odejść zawczasu. Inaczej, po wyświęceniu dolączą do kapłanów bezbożnych i gorszycieli.

Nauka druga traktowała o grzechu w ogóle, a w szczególności piętnowała chciwość u kaplana, powodująca zgorszenie u ludzi i hańbiąca stan duchowny

\footnotetext{
8 W. Malinowski, Opisanie, s. 33-34.

9 Tamże, s. 34.

10 Bibl. Ossolin., Rkps 949: Czute uwagi, k. 1v-3.
} 
(,jeżeli trzech groszy nie dodasz, nie pochowam cię"). Wiele zażaleń w tym względzie dociera do biskupa od wiernych. Nie należy zasłaniać zachlanności potrzebą pomocy dla ubogich krewnych. Mówca, świadom ograniczonych możliwości poprawy dawno wyświęconych, wolal: „O mlodzieży duchowna! Mlodzieży, na której nadzieja Kościola świętego i moja!"

W następnej konferencji biskup mówił o niegodnym przyjmowaniu Komunii. Przykładem Judasz. Byloby straszne, gdyby $w$ przyszłości śviętokradzko stawali do Mszy św. „Biada wam tu, i jeżeli straszliwą oltarza ofiarę jedynie dlatego odprawiać będziecie, abyście zysk doczesny odebrali, bo to będzie już zarodem nieszczęść waszych". Konsekwencja jest ozięblość, niedbalstwo w nauczaniu, nieznajomość podstawowych prawd wiary u wiemych. Spotykał to nierzadko, wizytując diecezję. Winę za lekceważenie religii ponoszą źli kapłani. Księdzu, jako przewodnikowi ludu i duszpasterzowi, potrzebna jest odpowicdnia wiedza. Nie tylko, „ażeby wyjaśniać prawdy odwieczne prostaczkom, |ale] i wyżej stojącym. Bo cóż, jeśli ci naraz zacznie jakiś tam lekkomyślny bezbożnik to lub owo, jakże sobie postąpisz? Jeśli będziesz mógl ujść - twoje szczęście. Ale gdy tego nie bẹdzie można uczynić bez oczywistego zhańbienia religii, i wlasnego wstydu, to powiesz coś takiego, co tylko ciebie na pośmiech, a religię na większe wyszydzenie wystawi. A czasem nawet ust nie będziesz śmial, a raczej nie bẹdziesz mógl, otworzyć. Dlatego waszym to rzemiosłem jest, aby nie tylko umieć chwytać tych prostaczków, te rybki, które same lezą $w$ sieć Chrystusowa, ale i one wielkie i harde ryby, co gwaltem z niej wydrzeć się pragną"11.

W kontekście tych słów latwiej zrozumieć motywy starań biskupa o wlączenie Wydzialu w umysłowe formowanie duchowieństwa. Podobne racje kierowały jego poprzednikami, którzy pojeli, iż szanse oddziaływania zyskuje katolicyzm oświecony, a traci sarmacki i rytualny. Dlatego bp Andrzej Stanisław Zaluski założył w 1758 r. Seminarium Akademickie (polączone przez Austriaków w 1801 r. z zamkowym i stradomskim), a Michał Poniatowski przedłużal czas edukacji seminaryjnej i poprawiał jej profil. Sam zaś Woronicz mial dość okazji, by w czasie swej wieloletniej działalności warszawskiej przyglądnąc się dobrze owym "hardym rybom". Akcentował więc potrzebę wyksztalcenia, zwlaszcza teologicznego, u przyszlych księży. „Mówiąc zaś o nieoświeceniu kapłanów, nie rozumiem ja tutaj, aby posiadal geografiç, astromonieç itu. (iubo by mu to nie szkodziło), ale mowię o umiejętnościach stanu jego, niezbędnie potrzebnych".

Ostatnia konferencja poświęcona byla pijaństwu i nieczystości. Traktujac - tej drugiej mówca używał mocnych określeń w rodzaju: "szkaradny występck", "haniebna zbrodnia nieczystości”, "bydlęca chuć, która plami i niszczy cialo, a tym bardziej duszę". Kaplan celebrujący, jeśli w takim

11 Tamże, k. 2-9v. 
grzechu "do tych straszliwych ofiar, które aniołów przerażaja" przystępuje, jest potworem. "Ale ta materia zbyt jest śliska, odsuńmy myśl naszą od niej, bo sam jej oddech zaraża". Źródel pijaństwa wśród księży dopatrywal się biskup $w$ braku zainteresowań intelektualnych. Nudę i trudności życiowe chce się wówczas utopić w trunku. Prostacka to zbrodnia duszy i ciała. Podsumowujac swoje rozważania, rekolekcjonista podkreślil trzy źródla wszelkiego zla w życiu kaplańskim: rozwiązłość, chciwość i pijaństwo. Jako środki zaradcze podawal: nabożeństwo do Najśw. Maryi Panny, do św. Wincentego i patronów młodzieży, Alojzego Gonzagi i Stanisława Kostki ${ }^{12}$.

Sklonności do zachęcenia do dobra poprzez odstręczanie od zła, dawnej chyba jak samo kaznodziejstwo, ulegl i wybitny skądiną mówca Woronicz. Potrzasal awansem sumieniami, wolnymi wszak choćby $z$ braku okazji np. od grzechu zdzierstwa. Pozytywnie uzasadnil chyba jedynie potrzebę przykładania się do studiów. Grzmial na temat nieczystości, a nie umiał przedstawić tego co wartościowe $w$ celibacie. Wolał też biadać nad pijaństwem, niż ukazywać walory trzeźwości. Nazajutrz po spowiedzi i Komunii kleryków, alarmowal ostrzegając przed świętokradztwem. O fascynujacej sile i pięknie dobra mówil mało, za to szeroko przedstawial zlo. Trwożyl swych mlodych sluchaczy, malując w przeraźliwych kolorach skutki nałogów. Wolał obrzydzać grzech, niż zachęcać do cnoty. Dotykał granicy, za która budowanie nie nadąża już za burzeniem. Pesymistyczna tonacja wyrastała nie tylko ze znajomości życia, ale i z melancholijnego usposobienia, nie liczạc manichejskich osadów w stosowanej na ówczesnych ambonach antropologii.

12 Tamże, k. 12 v-12. 